\title{
PENTINGNYA PERAN PERENCANAAN KEPERAWATAN BAGI PERAWAT RS
}

\section{MUTIARA UNVI ZAHRA}

\section{EMAIL : zahrazahrabatam845@gmail.com}

\section{LATAR BELAKANG}

Rumah sakit merupakan bagian integral dari keseluruhan sistem pelayanan kesehatan yang melayani pasien dengan berbagai jenis pelayanan. Departemen Kesehatan Republik Indonesia telah menggariskan bahwa rumah sakit umum mempunyai tugas melaksanakan upaya kesehatan secara berdayaguna dan berhasilguna dengan mengutamakan upaya kuratif dan rehabilitatif yang dilaksanakan secara serasi dan terpadu dengan upaya promotif dan preventif serta melaksanakan upaya rujukan (Depkes RI, 2001).

Rumah sakit merupakan suatu institusi pelayanan kesehatan yang kompleks dan juga komponen yang sangat penting dalam meningkatkan status kesehatan baagi masyarakat. Pengelolaan pelayanan dan asuhan keperawatan merupakan salah satu fungsi rumah sakit yang merupakan bagian dari system pelayanan kesehatan yang bertujuan mempertahankan status kesehatan masyarakat seoptimal mungkin. Rumah sakit sebagai salah satu tatanan pemberian asuhan keperawatan kepada masyarakat yang harus mampu menyediakan berbagai jenis pelayanan kesehatan yang kompleks dan berkualitas (Ilyas, 2007).

Pelayanan keperawatan merupakan bagian integral dari pelayanan kesehatan di rumah sakit, yang mempunyai posisi yang sangat strategis dalam upaya meningkatkan mutu pelayanan dan pemuasan konsumen yang datang ke rumah sakit. Jumlah tenaga keperawatan mendominasi tenaga kesehatan secara menyeluruh, juga sebagai penjalin kontak pertama dan terlama dengan pelanggan (pasien dan keluarganya).

Keperawatan adalah suatu bentuk pelayanan professional yang merupakan bagian integral dari pelayanan kesehatan berdasarkan ilmu dan kiat keperawatan berbentuk pelayanan biologis, psikologis, sosiologis dan spiritual yang komprehensif/holistik yang ditujukan kepada individu, keluarga dan masyarakat baik dalam keadaan sehat atau sakit yang 
mencakup seluruh proses kehidupan manusia yang mengacu pada standar profesional keperawatan dan menggunakan etika keperawatan sebagai tuntutan utama (Nursalam, 2011).

Undang-undang RI No. 36 tahun 2009 tentang kesehatan menyatakan bahwa setiap peningkatan mutu pelayanan kesehatan harus disertai dengan peningkatan mutu pelayanan keperawatan (UU Kesehatan RI, 2009). Dalam undang-undang RI No. 38 tahun 2014 tentang keperawatan pasal 31 ayat 2, menjelaskan bahwa dalam menjalankan tugasnya sebagai pengelola pelayanan keperawatan, perawat berwenang : melakukan pengkajian dan menetapkan permasalahan, merencanakan, melaksanakan dan mengevaluasi pelayanan keperawatan dan mengelola kasus (UU Keperawatan, 2014).

Proses keperawatan adalah suatu sistem yang mengatur perencanaan di dalam pelayanan kesehatan yang dimulai dari tahap pengkajian sampai tahap evaluasi yang dilakukan berdasarkan kaidah keperawatan. Salah satu tahap di dalam proses keperawatan adalah perencanaan keperawatan. Perencanaan keperawatan adalah penyusunan rencana tindakan keperawatan yang akan dilakukan perawat di dalam mengatasi permasalahan sesuai dengan diagnosis yang telah di tentukan dengan tujuan terpenuhinya kesehatan pasien.

Perencanaan keperawatan dilakukan perawat di dasarkan oleh pengetahuan dan penilaian klinis agar mendapatkan hasil yang diharapkan. perencanaan keperawatan juga menentukan atau berpengaruh terhadap proses keperawatan selanjutnya, sehingga harus dilakukan dengan segala pertimbangan berdasarkan teori-teori yang ada. Perencanaan keperawatan dilakukan sebagai penentuan langkah-langkah didalam pemecahan masalah seperti perumusan tujuan, rencana tindakan, serta penilaian asuhan keperawatan yang telah dilakukan kepada pasien. Pengkajian keperawataan ini merupakan strategi untuk mencegah, mengurangi, dan mengkoreksi permasalahan yang telah diidentifikasi sebelumnya pada tahap diagnosa keperawatan.

Perencanan keperawatan disusun dan dirumuskan oleh perawat bersama keluarga atau orang terdekat pasien agar keberhasilan asuhan keperawatan dapat ditingkatkan. Sehingga perawat harus mampu memberikan penjelasan terkait perencanaan asuhan keperawatan agar keluarga atau orang terdekat pasien dapat diajak bekerja sama. 
Rencana keperawatan yang disusun perawat kepada pasien akan berbeda setiap pasiennya. Oleh karena itu, setiap pasien di ruang rawat inap akan memiliki rencana keperawatan yang berbeda, meskipun berada di satu ruangan yang sama, karena tiap pasien dapat memiliki keluhan yang berbeda. Perawat terlebih dahulu harus mampu untuk mengkaji keluhan-keluhan yang ada, menentukan diagnosa, dan setelah itu baru dapat menyusun rencana keperawatan.

Tahap lainnya dari proses keperawatan adalah implementasi. Implementasi adalah pengelolaan dan perwujudan dari rencana keperawatan yang telah perawat susun pada tahap perencanan. Sehingga antara perencanaan dan implementasi mempunyai hubungan yang sangat erat. Pelaksanaan rencana tindakan yang ditentukan mempunyai tujuan agar kebutuhan pasien terpenuhi secara maksimal yang mencakup aspek peningkatan, pencegahan, pemeliharaan serta pemulihan kesehatan.

\section{METODE}

Metode yang saya gunakan dalam membuat kajian ini adalah dengan menggunakan metode literature review. Dimana saya membaca beberapa referensi seperti jurnal ataupun buku-buku yang mendukung. Jurnal jurnal serta buku maupun ebook yang saya gunakan saya kumpulkan memlaui media media seperti google scholar, e-book, maupun jurnal luar seperti Elsevier. Setelah membaca beberapa referensi, saya mengkaji dan membuat analisnya. Analisis dibuat sesuai thema judul yang saya ambil yaitu pentingnya peran perencanaan asuhan keperawatan bagi perawat rs.

\section{HASIL}

Dari hasil kajian saya didapatkan bahwa perencaan asuhan keperawatan memiliki peran yang sangat penting dan besar dalam pemberian asuhan keperawtan. Perencanaan keperawatan dilakukan untuk membuat asuhan keperawatan dengan benar dan tepat serta mengetahui apa apa saja peran perawat, pengertian perawat, asuhan keperawatan agar dapat di tata dalam perencanaan guna mencapai suatu hasil yang baik dan tepat. Tujuan keperawatan yakni membantu individu meraih kesehatan yang optimal dan tingkat fungsi maksimal yang mungkin bisa diraih setiap indifidu. Peran perawat yaitu untuk meningkatkan kesehatan dan mencegah penyakit, sementara peran perawat sebagai care giver merupakan peran yang sangat penting dari peran-peran yang lain (bukan berarti peran yang lain tidak penting) 
karena baik tidaknya layanan profesi keperawatan dirasakan langsung oleh pasien.

Maka dari itu kepuasaan pasien juga termasuk hal yang penting, kepuasan pasien ialah suatu tingkat perasaan pasien yang timbul sebagai akibat dari kinerja pelayanan kesehatan yang diperoleh setelah pasien membandingkannya dengan apa yang diharapkannya. Pasien baru akan merasa puas apabila kinerja pelayanan kesehatan yang diperolehnya sama atau melebihi dari pada yang diharapkannya dan sebaliknya, ketidakpuasan akan timbul atau perasaan kecewa pasien akan terjadi apabila kinerja palayanan kesehatan yang diperolehnya tidak sesuai harapanya.

Perawat yang peduli dengan kebutuhan biologis, psikologis, dan sosialbudaya pasien, melihat pengalaman manusia dalam cakupan yang luas. Mereka harus belajar mengatasi ansietas, kemarahan, kesedihan dan keceriaan, dalam membantu pasien sepanjang rentang sehat-sakit. Sedangkan menurut pemberian asuhan keperawatan mencakup asuhan fisik, psikososial, perkembangan, budaya, dan spiritual.

Peran perawat utama dari perawat kesehatan masyarakat adalah memberikan asuhan keperawatan pada individu, keluarga, kelompok dan masyarakat baik yang sehat maupun yang sakit atau yang mempunyai masalah kesehatan/keperawatan apakah itu dirumah, sekolah, panti dan sebagainya sesuai kebutuhan. Rencana perawatan dapat juga mengidentifikasi dan mengoordinasi sumber yang digunakan untuk memberikan asuhan keperawatan. Membuat daftar dari peralatan dan suplai spesifik untuk tindakan keperawatan adalah suatu metoda yng murah untuk memilih peralatan. Jika semua peralatan dan suplai dimasukkan di dalam rencana perawatan, maka wakth perawat dapat digunakan lebih efektif dalam memberikan asuhan.

\section{PEMBAHASAN}

Meningkatnya tuntutan masyarakat akan sarana kesehatan terutama di Rumah Sakit, secara berkesinambungan membuat Rumah Sakit harus melakukan upaya peningkatan mutu pemberian pelayanan kesehatan. Salah satu mutu pelayanan kesehatan yang harus ditingkatkan secara berkesinambungan adalah mutu pelayanan keperawatan di Rumah Sakit (Kementerian Kesehatan Republik Indonesia, 2012).

Setiap upaya untuk meningkatkan kualitas pelayanan Rumah Sakit harus juga disertai upaya untuk meningkatkan kualitas pelayanan keperawatan. (Mulyono et al, 
2013) Pelayanan keperawatan sebagai bagian integral dari pelayanan kesehatan mempunyai daya ungkit yang besar dalam mencapai tujuan pembangunan bidang kesehatan.

Keperawatan sebagai profesi dan perawat sebagai tenaga professional bertanggungjawab untuk memberikan pelayanan keperawatan sesuai kompetensi dan kewenangan yang dimiliki secara mandiri maupun bekerjasama dengan anggota tim kesehatan lain. Pelayanan keperawatan yang bermutu merupakan tujuan yang ingin dicapai oleh perawat. Keperawatan sebagai profesi yang merupakan bagian dari masyarakat akan terus berubah sejalan dengan masyarakat yang terus berkembang dan mengalami perubahan.

Keperawatan dapat dilihat dari berbagai aspek, antara lain keperawatan sebagai bentuk asuhan profesional kepada masyarakat, keperawatan sebagai ilmu pengetahuan dan teknologi (Iptek), serta keperawatan sebagai kelompok masyarakat ilmuwan dan kelompok masyarakat professional. Dengan terjadinya perubahan atau pergeseran dari berbagai faktor yang mempengaruhi keperawatan, akan berdampak pada perubahan pelayanan/asuhan keperawatan, perkembangan Iptek keperawatan, maupun perubahan dalam masyarakat keperawatan, baik sebagai masyarakat ilmuwan maupun sebagai masyarakat profesional (Nursalam, 2015).

Undang-Undang Republik Indonesia nomor 36 tahun 2009, menyatakan bahwa setiap peningkatan mutu pelayanan kesehatan harus disertai dengan peningkatan mutu pelayanan keperawatan. Terjadinya pergeseran paradigma dalam pemberian pelayanan kesehatan dari model medikal yang menitikberatkan pelayanan pada diagnosis penyakit dan pengobatan (kuratif) ke paradigma sehat yang lebih holistik yang melihat penyakit dan gejala sebagai informasi dan bukan sebagai fokus pelayanan.

Undang-undang tersebut sejalan dengan Undang-Undang Republik Indonesia Nomor 38 tentang Keperawatan tahun 2014, yang menyatakan bahwa pelayanan keperawatan adalah suatu bentuk pelayanan profesional yang merupakan bagian integral dari pelayanan kesehatan yang didasarkan pada ilmu dan kiat keperawatan ditujukan kepada individu, keluarga, kelompok, atau masyarakat, baik sehat maupun sakit. Salah satu upaya yang sangat penting dalam meningkatkan mutu pelayanan keperawatan 
adalah meningkatkan sumber daya manusia dan manajemen keperawatan (Marquis and Huston, 2010). Rumah Sakit merupakan sarana penyedia layanan kesehatan untuk masyarakat.

Rumah Sakit sebagai institusi penyedia jasa pelayanan kesehatan perorangan secara paripurna memiliki peran yang sangat strategis untuk mewujudkan derajat kesehatan yang setinggi-tingginya (UndangUndang Republik Indonesia Nomor 44 tahun 2009). Rumah Sakit dituntut untuk memberikan pelayanan yang bermutu sesuai dengan standar yang ditetapkan dan dapat menjangkau seluruh lapisan masyarakat.

Perencanaan keperawatan disusun bergantung dan berdasarkan dari hasil pengkajian. Setelah melewati tahap pengkajian, maka setiap asuhan keperawatan dilanjutkan dengan analisis dan pengelompokkan secara sistematik terhadap data bjektif maupun subjektif untuk merumuskan diagnosis keperawatan, yang terfokus pada dua hal, yaitu:

1) Status kesehatan klien,

2) Kekuatan pasien yang menggambarkan

Komponen perencanaan keperawatan menurut (Nursalam, 2012), adalah :
Prioritas masalah dengan kriteria : masalah-masalah yang mengancam kehidupan merupakan prioritas pertama, masalah-masalah yang mengancam kesehatan seseorang adalah prioritas kedua, masalah-masalah yang mempengaruhi perilaku merupakan prioritas ketiga. Menurut Marquis \& Huston, perubahan yang tidak terduga yang telah terjadi atau apabila mendapatkan informasi baru dari pasien yang dapat mengubah rencana awal, maka perawat dapat kembali menetapkan prioritas baru atau menyesuaikan prioritas berdasarkan siatuasi yang sedang berlangsung.

Tujuan asuhan keperawatan dengan kriteria : spesifik, bisa diukur, bisa dicapai, realistik, ada batas waktu. Dengan menentukan tujuan dan kriteria hasil diharapkan asuhan keperawatan yang diberikan akan memberikan keberhasilan sesuai dengan 
tujuan yang diharapkan klien maupun perawat.

Rencana tindakan dengan kriteria : disusun berdasarkan tujuan asuhan keperawatan, melibatkan pasien/keluarga, mempertimbangkan latar belakang budaya pasien/keluarga, menentukan alternative tindakan yang tepat, mempertimbangkan kebijaksanaan dan peraturan yang berlaku, lingkungan, sumberdaya dan fasilitas yang ada, menjamin rasa aman dan nyaman bagi pasien, kalimat instruksi, ringkas, tegas dengan bahasanya mudah dimengerti

Menurut (PPNI, 2009), rencana tindakan keperawatan dikembangkan berdasarkan diagnosis keperawatan, mencakup:

1) Kriteria struktur: tatanan praktik menyediakan:

sarana yang
dibutuhkan dalam
perencanaan
keperawatan
$>$ adanya mekanisme
pencatatan dan

perencanaan sehingga dapat digunakan kembali

dikomunikasikan

2) Kriteria proses: perencanaan terdiri dari penetapan prioritas masalah, tujuan, dan rencana tindakan keperawatan. Bekerjasama dengan klien dalam menyusun rencana tindakan keperawatan. Perencanaan bersifat individual (sebagai individu, kelmpok, dan masyarakat) sesuai dengan kondisi atau kebutuhan lain

3) Kriteria hasil: 1 .

$>$ Tersusunnya rencana asuhan keperawatan

$>$ Perencanaan mencerminkan penyelesaianterhadap diagnosis keperawatan

$>$ Perencanaan tertulis dalam format yang singkat dan mudah di fahami

$>$ Perencanaan menunjukkan bukti adanya revisi pencapaian tujuan

Proses perencanaan meliputi perumusan tujuan dan menentukan intervensi yang tepat. Proses ini dimulai dengan membuat daftar semua masalah-masalah pasien dan mencari masukan dari pasien, keluarga atau orang terdekat pasien tentang penentuan tujuan 
akhir yang dapat diterima dan dapat dicapai secara rasional. Pernyataan tujuan akhir harus dinyatakan dalam bentuk pernyataan yang dapat diukur, yang secara obyektif menunjukann perkembangan terhadap pemecahan masalah yang ditemukan. Bagian lain dari perecanaan keperawatan adalah menentukan intervensi yang digunakan perawat dengan melibatkan pasien dan keluarga untuk mencapai tujuan yang telah ditetapkan.

Rencana asuhan keperawatan harus dibuat secara spesifik, jelas, jangka waktu ditentukan, dapat diukur baik kognitif, afektif, dan psikomotor. Jenis intervensi keperawatan harus mencantumkan therapi keperawatan, pendidikan kesehatan, kolaborasi dengan Tim kesehatan lain, observasi dan monitoring. Perawat di dalam memberikan asuhan keperawatan harus mempunyai perencanaan waktu di dalam melakukan tindakannya. Adanya perencanaan waktu dibutuhkan untuk mencapai tujuan awal yang telah ditetapkan, mendisiplinkan diri perawat, dapat berpikir kritis dan dapat meningkatkan tingkat keberhasilan asuhan keperawatan. Pada ruangan rawat inap, perawat yang bertugas harus terlihat selalu siap akan perubahan kondisi pasien atau jika ada informasi baru.
Dengan mempunyai perencanaan waktu yang ideal, perawat dapat mengambil dan memperkirakan suatu keputusan dengan baik dan efektif. Pelaksanaan (implementasi) adalah pengelolaan dan perwujudan dari rencana keperawatan yang telah di susun pada tahap perencanaan (Butcher, 2012). Pada tahap implementasi keperawatan, perawat memerlukan tenaga dan fokus yang paling tinggi karena berhubungan dengan tindakan invasif terhadap pasien.

Menurut (PPNI, 2009), perawat mengimplementasikan tindakan yang telah diidentifikasikasi dalam rencana asuhan keperawatan yang mencakup:

Rasional: perawat mengimplementasikan rencana asuhan keperawatan untuk mencapai tujuan yang telah ditetapkan.

Kriteria struktur: Tatanan praktik menyediakan: sumber daya untuk pelaksana kegiatan, pola ketenagakerjaan yang sesuai kebutuhan, adanya mekanisme untuk mengkaji dan merevisi pola ketenangan secara periodik, melakukan supervisi terhadap tenaga 
pelaksana keperawatan di bawah tanggung jawabnya, menjadi koordinator pelayanan dan advokasi terhadap klien untuk mencapai tujuan kesehatan, menginformasikan kepada pasien tentang status kesehatan dan fasilitasfasilitas pelayanan kesehatan yang ada, memberikan pendidikan pada klien dan keluarga mengenai konsep dan keterampilan asuhan diri serta membantu klien memodifikasi lingkungan yang digunakan, mengkaji ulang dan merevisi pelaksanaan tindakan keperawatan berdasarkan respon klien.

Kriteria hasil: terdokumentasi tindakan keperawatan dan respon klien secara sistematik dan dengan mudah diperoleh kembali, tindakan keperaawatan dapat diterima oleh klien dan keluarga, ada bukti-bukti yang terukur tentang pencapaian tujuan.
Metode-metode implementasi diantaranya adalah:

Membantu dalam aktivitas kehidupan sehari-hari (AKS), aktivitas tersebut mencakup ambulansi, makan, berpakaian, mandi,menyikat gigi, dan berhias. Kondisi yang mengakibatkan kebutuhan AKS dapat bersifat aakut, kronis, temporer, maupun permanen. Sebagai contoh, pasien pasca operasi yang tidak mampu secara mandiri menyelesaikan semua AKS.

Konseling. Konseling merupakan metode implementasi yang membantu pasien menggunakan proses penyesuaian masalah untuk mengenali dan menangani stress dan yang memudahkan hubungan interpersonal di antara pasien, keluarganya, dan tim perawatan kesehatan.

Penyuluhan. Digunakan dengan menyajikan prinsip, prosedur, dan teknik yang tepat tentang perawatan kesehatan untuk pasien dan 


untuk menginformasikan
pasien tentang status
kesehatannya
Memberikan
keperawatan langsung untuk
mencapai tujuan terapeutik
pasien, perawat melakukan
intervensi untuk mengurangi
resiko yang merugikan
dengan menggunakan
tindakan pencegahan dan
preventif dalam memberikan
asuhan.

\section{PENUTUP}

Perencanaan keperawatan adalah salah satu dari proses keperawatan yang dilakukan dengan menyusun rencana tindakan yang akan dilakukan dalam rangka mengatasi masalah-masalah pasien. Perencanaan keperawatan ini sendiri memiliki peran yang amat sangat penting, yaitu dengan melakukan perencaaan keperawatan perawat dapat memberikan pelayan dan asuhan keperawatan secara maksimal dan mengurangi resiko komplikasi. Hal ini juga akan berdampak pada peningkatan mutu layanan rumah sakit itu sendiri.

\section{DAFTAR PUSTAKA}

* Abd. Wahid dan Imam Suprapto. (2012). Dokumentasi Proses Keperawatan. Yogyakarta :Nuha Medika

Aini, D. N. (2018). Hubungan Kualitas Pelayanan Keperawatan dengan Tingkat Kepuasan Pasien Rawat Inap di RSUD DR. H. SOEWONDO KENDAL. Jurnal Ners Widya Husada Semarang , 2.

* Anggeria, E., Maria. (2018). Hubungan Supervisi Dengan Pelaksanaan Asuhan Keperawatan di Ruang Rawat Inap Lantai 10 Rumah Sakit Umum Royal Prima Medan Tahun 2017. Jurnal JUMANTIK, 3(2), 78-97.

- Butar-Butar, J., \& Simamora, R. H. (2016). Hubungan Mutu Pelayanan Keperawatan dengan Tingkat Kepuasan Pasien Rawat Inap di RSUD Pandan Kabupaten Tapanuli Tengah. Jurnal Ners Indonesia, 6(1), 50-63.

* Dermawan, D. (2012). Proses Keperawatan: Penerapan Konsep \& Kerangka Kerja. Yogyakarta : Gosyen. 
Gobel, S.G.M., Mulyadi., \& Malara, T.M. (2016). HUBUNGAN PERAN PARAWAT SEBAGAI CARE GIVER DENGAN TINGKAT KEPUASAN PASIEN INSTALASI GAWAT DARURAT DI RSU. GMIBM MONOMPIA KOTAMOBAGU KABUPATEN BOLAANG MONGONDOW. ejournal Keperawatan, 4(2), 1-7.

* Harefa, D. (2019). Aplikasi Berpikir Kritis Dan Bertindak Dalam Proses Keperawatan. osf.io.

* Hidayah, N. (2014). Manajemen Model Asuhan Keperawatan Professional (MAKP) dalam Peningkatan Kepuasan Pasien di Rumah Sakit. Jurnal Kesehatan, 7(2), 410-426.

* Indriatie. (2013). Berfikir Kritis dalam Proses Keperawatan. Jurnal Keperawatan, 7,(2), 89-93.

* Jumairah, T., \& Mulyadi, B. (2017).

Peran Perawat Dalam Pelaksanaan Perawatan Kesehatan Masyarakat (Perkesmas). Jurnal Ilmu Keperawatan Indonesia, 7(1), 182188.

* Kodim, Yulianingsih. (2015). Konsep Dasar Keperawatan. Jakarta: CV. Trans Info Media.
* Kuntarti. \& Nurmalia, L. (2017). PENGETAHUAN DAN MOTIVASI PERAWAT BERPERAN PENTING DALAM MENGATASI MASALAH TIDUR DI RUMAH SAKIT. Jurnal Keperawatan Indonesia, 20(3), 176184.

* Nogo, A. (2014). Kinerja Perawat Dalam Penerapan Standar Asuhan Keperawatan di Rumah Sakit Umum Daerah Naibonat Kabupaten Kupang. Jurnal Penelitian, 18, 62-66.

* Nursalam. Edisi 3. (2013). Metodeologi Penelitian Ilmu Keperawatan Pendekatan Praktis. Jakarta: Salemba Medika.

* Pusdik SDM Kesehatan. (2016). Dokumentasi Keperawatan. Jakarta Selatan: Penulis.

* Simamora, R. H. (2005). Hubungan Persepsi Perawat Pelaksana Terhadap Penerapan Fungsi Pengorganisasian Yang Dilakukan Oleh Kepala Ruangan Dengan Kinerjanya Diruang Rawat Inap RSUD Koja Jakarta Utara (Doctoral dissertation, Tesis FIK UI, Tidak dipublikasikan).

* Wahyudi, I. (2020). PENGALAMAN PERAWAT MENJALANI PERAN DAN FUNGSI PERAWAT DI 


\section{PUSKESMAS KABUPATEN \\ GARUT. Jurnal Sahabat}

Keperawatan, 2(1), 36- 43. 